\title{
Analytical Study of Imam Shami's Tafseeri Points to Quote Surat Al-Fattiha in Sublul Huda
}

\section{ABSTRACT:}

*Muhammad Akram Hurery

"* Dr. Mohd Roslan Mohd nor

Imam Abdullah Muhammad bin Yusuf Shami RA (942 h) was one of the most important personalities in the history of Islam. He wrote many books in Islamic points of view. One of the most important and significant his book belongs to Seerah of Muhammad PBUH, which is in fourteen volumes. In that book, Imam Shami RA wrote many verses of the Holy Quran to describe Seerah of Holy Prophet PBUH. We added verses of Surat Al Fatiha in this article that are used in Imam Shami's book (Sublul Huda Wal Rashad fi Seerat-e-Khair-e-Ebad) to know his Tafseeri points. He often wrote one verse of the Holy Quran at different places and chapters of Sublul Huda, and he got different meanings and concepts from that verse to narrate Seerah al Nabwya (pbuh) in Sublul Huda. In this article, it is analyzed the tafseeri points of Imam Sham with other mufassirin to get meanings from verses. What is the different way of Imam Shami to describes Seerat-ul-Nabi (pbuh) and what are the findings of tafseeri points discussed in Sublul Huda.

Keywords: Imam Shami, Sublul Huda, Surat al Fateha, Tafseeri Points, Seerah.

\section{Introduction of Auther:}

'Imam Shami's name is Muhammad Bin Yousaf (942 h). His grandfather's name is Ali and his great grand father's name is Yousaf. Thus, grandfather's name and great grandfather's name is the same. "Title", Shamas-ud-Deen; the patronymic name is Abu Abdullah and association is Al-Salehi, Al-Dameshqi, Al-Shami, Al-Shafi, AlQaderi, and Al-Misri. The most famous association is Shammi. The renowned historian, dignified writer of the Holy Prophet's (PBUH) autobiography, the distinguished narrator of the Ahadith; was born in satellite town "Al-Salehat" of an ancient city; the Damascus; the Syrian capital" .It is said that in ancient times, it was known as "Riyaul-Nakhal and Qaryat-ul-Jabal". This place is one of the sacred and blessed places of mountain "Qaseeyoon". There are Prophets' and many saints' graves, near this mountain. There is also an aria of Syedna Ibrahim Prophet's birth ${ }^{2}$.

\section{Introduction of Book:}

Basically, Subul-Hudda is a book of Seerat ul Nabi. Its full name is Sublul Huda wal

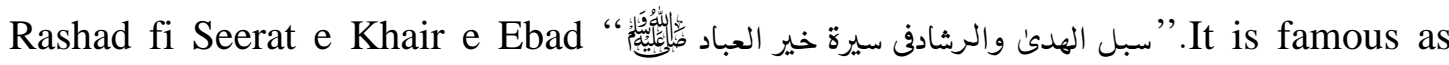
"Seerat-e- Shami". Imam Shami has written/composed it after studying one thousand books. Its author's name is known as "Muhammad Bin Yousaf Bin Ali Bin Yousaf, Title, Shamas-ud-Deen; the patronymic name is Abu Abdullah and association is Al-

"Research Associate at University of Malaya, Kualalumpur Malaysia / PhD Scholar, AIOU Islamabad. Email: mahurary@gmail.com

"Associate Professor, Academy of Islamic Studies University of Malaya, Malaysia. 
Salehi, Al-Dameshqi, Al-Shami, Al-Shafi, Al-Qaderi, and Al-Misri. The most famous association is Shammi. The detail is mentioned below;

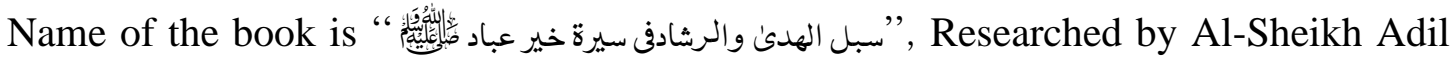
Ahmed Abdul Maujood RA, Al-Sheikh Ali Muhammad Mauwaz. Total volumes of the book are fourteen, Caligraphy on average 29 lines per page and 60 words per line. Date of Publication details as first published in 1414, Hijri/ 1993 to 1418, Hijri/1998, Publishers is Dar-ul-Kutabb Al-Ilmiya, Beirut, Lebanon.

Hand Written Scripts/Scriptures/Books, which have been mentioned in the preface of Al-Tahqeeq of Seerat-e-Shami; Volume 1and about these places it has also been pointed out that some publishers and researchers have been benefitted; while they were researching upon the text of the handwritten book's information about these places is given below;

1. Maahad Al-Makhtootaat Al-Arabia Al-Cairo-Here only the fourth; the last part of the book is present.

2. Dar-ul-Kutab Al-Egyptian, Maktaba Mustafa Fazal- This handwritten book has consisted of a third and fourth part.

3. Dar-ul-Kutab Al-Egyptian, Maktaba al-Taemooriya

4. Dar-ul-Kutab Al-Egyptian, Maktaba Talatt- these prescriptions consist of 3 parts.

5. Dar-ul-Kutab Al-Egyptian, this prescription consists of different parts.

6. Dar-ul-Kutab Al-Egyptian, this prescription also consists of different parts.

7. On the sidelines of the preface of the Seerat Ibne Hashaam explanation of two scripts of Subul-Huda has been presented in these words; two handwritten scripts of SubulHuda are available in DarulKutab AlEgyptian and of these two ones is consisted of 4 parts and of second only two-part are available and these are 3rd and 5th. ${ }^{3}$

In this article, the study of the narration that Imam has made in connection with the verses of Surah Fatiha is included. Imam Shami has brought some verses of the Surah Al-Fatiha in his book. We have also presented in some places comparative interpretations of other commentators. And to describe Imam Shami as a narrator, and there is also a subtle difference between explaining the meaning of others, is made it a part of this article.

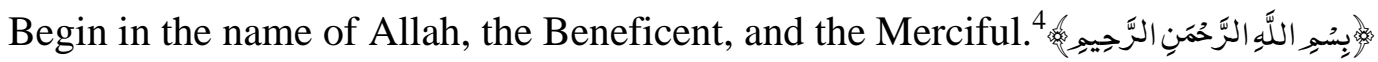
Imam Abdullah bin Yusuf Shami RA (942 h) brings this verse at two places in his book "Sublul Huda":

1. At first place, Allama Abdullah bin Yusuf Shami describes this verse in his book of Seerah "Sublul Huda", and brings it under the chapter on one of the important aspects of the sermon regarding compulsory meters (Fraiz).

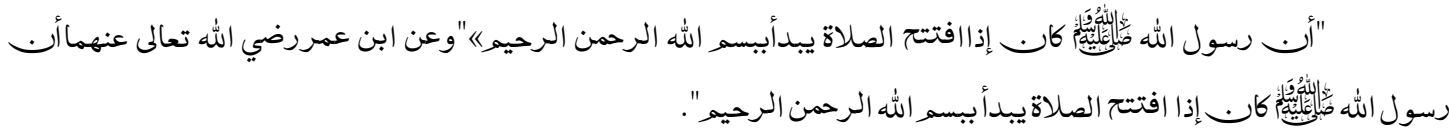

When the Messenger of Allah (PBUH) started praying, he used to Bismillah. ${ }^{5}$ This same hadeeth is narrated by Ibn 'Umar (May Allah be pleased with him. ${ }^{6}$ 
Imam Shami (may Allah have mercy on him) narrated the Seerah of the Holy Prophet that He used to read Bismillah at the beginning of the prayer, and in every rak'ah.

2. In another place, Al-Shami has brought this verse in the chapter on the recitation of the Qur'an with tajweed from the chapters regarding the etiquette the recitation of the Holy Qur'an. And every verse is mentioned here in separate recitation and counting, and this is also explained that "Bismillah" is the verse of the Surat Fateha.

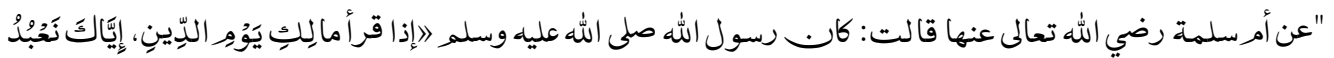

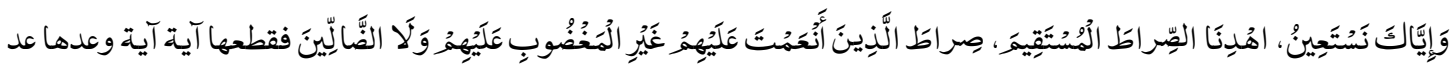

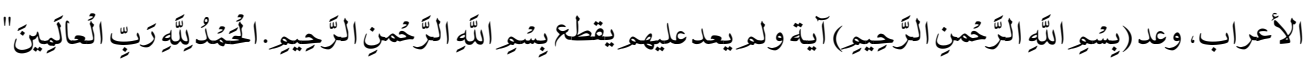

It is narrated from Hazrat Umm e Salima RA, when the Messenger of Allah (peace be

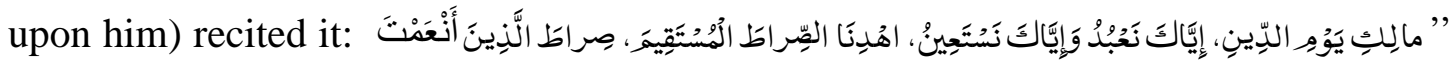

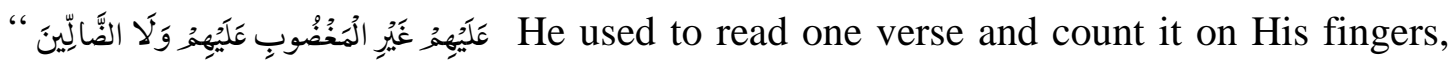

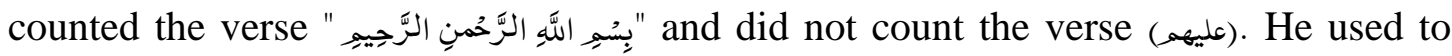

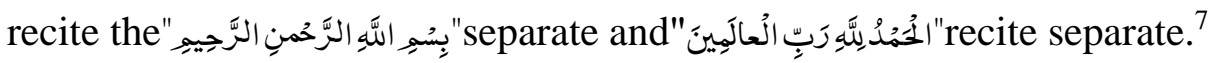

Al-Shami told us hereafter deriving from the Seerah of Holy Prophet PBUH that when He recited it, he used to read each verse one by one and lengthen it and that also told about Bismillah is the regular verse of Surah Al-Fatihah.

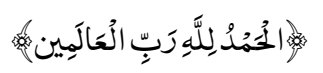

All praise is for Allah who is the Lord of all the worlds. ${ }^{8}$

Imam Abdullah bin Yusuf Shami RA ( $942 \mathrm{~h}$ ) brings this verse at four different places and chapters in his book "Sublul Huda":

1. At the first place, Al-Shami brings this verse in the chapter in which Surah Fatiha is mentioned as beginning with Praise be to Allah (الحمدلله) from the chapters on the important aspects of the compulsory prayer. Bismillah is proven both ways quietly

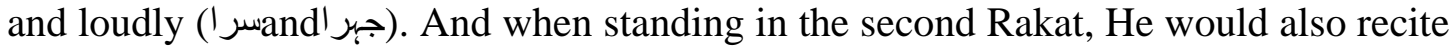
the recitation of the Qur'an with the words Praise be to Allah (الحمدلله):

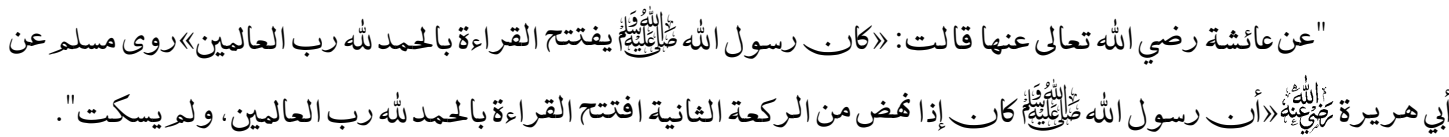

It is narrated from Sayeda Aisha RA (), He used to recite the recitation with alHamdullah Rabbal al-Amin. ${ }^{9}$ Imam Muslim narrates from Abu Hurairah that when the Messenger of Allah (PBUH) was standing for the second Rakat, He would start with Alhamdulillah and would not remain silent. ${ }^{10}$

Imam says that Bismillah used to read both loud and soft (both ways used). It is intended to say that whenever reciting the Qur'an in prayer, He would recite it from Alhamdulillah.

2. At the $2^{\text {nd }}$ place, Allama Shami described this verse under the chapter on rain, 
two sermons for rain, and the prayer without azan and iqama from the chapters of the Seerah regarding raining. People complained of famine, as a result, the prayer of rain is offered and He addressed the sermon before prayer (salat).

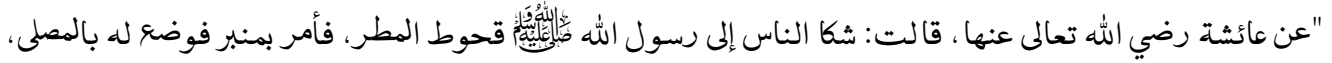

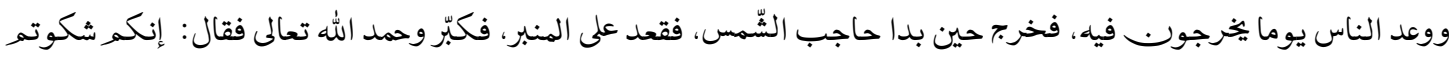

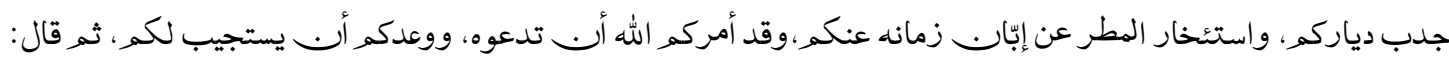

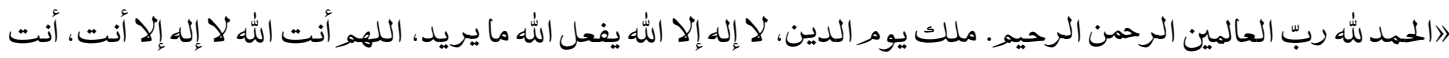

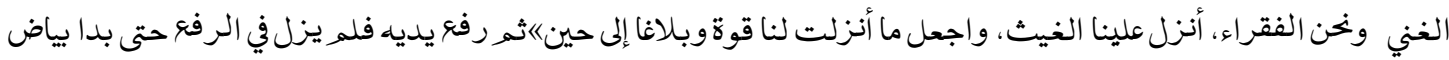

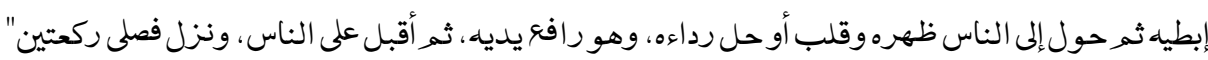

Sayyada Ayesha narrates that people complained to the Holy Prophet that there is no rain. So He ordered to place of the stage. I have placed a stage in Eid-gah. It was fixed a day for people. The day, they set out, when the flames of the sun appeared. The Holy Prophet PBUH came out, sited on stage and said Allah o Akber, praised to Allah. You have complained about the famine in your cities and told about the absence of rain. And Allah has commanded you to ask Him. He has promised that $\mathrm{He}$ will accept your request and then praised to Allah with these words:

$$
\text { "الحمد لهه ربّ العالهين الرحمن الرحيه ملك يومر الدين، لا إله إلا الهـ-_-موبلاغا إلى حين" }
$$

Then raise his hands - until the whiteness of His armpits began to appear. He turned His sheet over to the Companions, Keep His hands high, then intend towards the people and prayed two Rak'ats). ${ }^{11}$

3. At the $3^{\text {rd }}$ place, In the third place, Allama Shami mentioned this verse in the chapter of Seerah of Holy Prophet PBUH regarding the recitation of the Holy Quran From the chapters on the etiquette of recitation of the Qur'an, reading with tajweed doing a long voice.

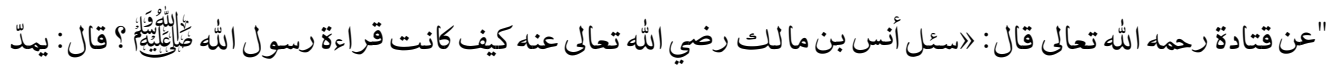

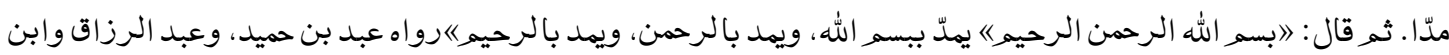

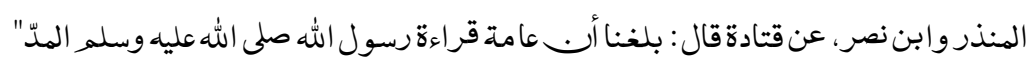

This is the statement of Qatadah RA, It is asked by Anas RA, what was the method of the Prophet to recite the Qur'an? He said that he used to read words lengthy and then recited Bismillah al Rehman al-Rahim, Bismillah read lengthy, read al-Rahman and al-Rahim also lengthy. ${ }^{12}$ And Ibn e Hameed, Abdul Razzaq, Ibn e Munjirah and Ibn e Nasr have quoted from Qatadah, we have reached this point, ordinary recitation of The Prophet PBUH was also long. ${ }^{13}$

In both these places, Imam Sha'ami mentions the recitation of the Holy Prophet (pbuh) under this verse. And he told us the manner and quality of the Holy Prophet's prayer PBUH. 
4. At the $4^{\text {th }}$ place, Imam Sha'ami interprets the "Aalamin" as saying:

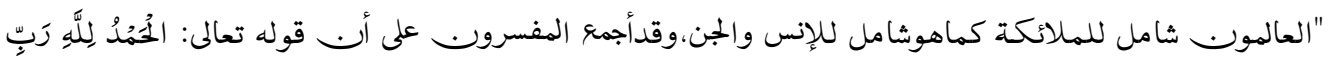

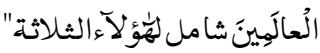

The universe includes angels like humans and jinn. There is a consensus of all commentators on this statement, that all three (angels, human and jinn) are including in al-Alamin ${ }^{14}$. While Imam ibn Jarir Tabari $(310 \mathrm{~h})$ did the commentary an 'AlAalamin' like this:

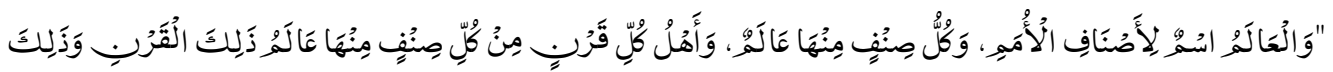

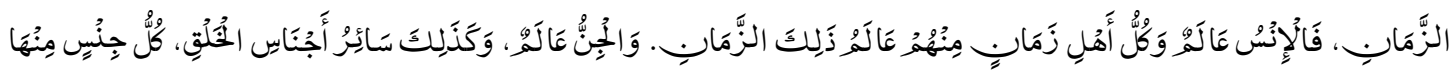

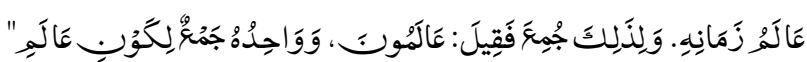

Types of creatures called the universe, each type of creature is a universe, a kind of people in every era is called the universe of this time, human beings are a universe, and the people of every era are its universe, a world of jinn, as well as every kind of creature, is the universe of its time. This is why the word (عالموتن) is used plural; the universe (عالم) also gives the meaning of the plural. ${ }^{15}$

Allah (SWT) is the One who fulfills all the needs of the angels, jinns and human beings. Everybody is a universe, and every gender is a different universe since Allah meets the necessities of every kind of creature, therefore, all praises are due to Allah, therefore Allah (SWT) says alhamdulillah e Rabb el Almin.

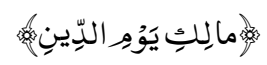

The owner of the Day of Judgment. ${ }^{16}$

Al-Shami brought this verse in miscellaneous etiquette of jihad is covered by chapter from the chapters on Seerah's view of jihad. There is mention of helping weak Muslims during the war and praying on this occasion for them with the words مالك يوم الدين-اياك نعبد Tو اياك نستعين To pray with words, the enemies of the Muslims were falling after being dead.

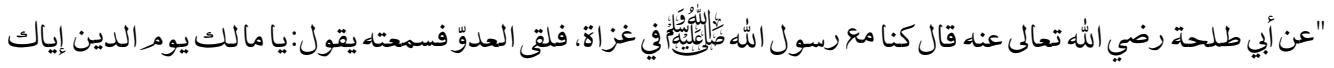

$$
\text { نعبدوإياك نستعين، قال : فلقدرأيت الرجال تصرو تضربها الهلائكة من بين أيديها ومن بخلفهال }
$$

Abu Talha said, "We were in a Ghazwa with the Prophet PBUH, I heard that HE said "يا مالك يو الدين، إيالك نعبد و إياك نستعين", I saw the people were falling after being dead. The angels were hitting them from the front and behind. ${ }^{17}$

Guide us to the straight path. ${ }^{18}{ }^{8}$

Imam Abdullah bin Yusuf Shami RA describes this verse at two different places and chapters in his book "Sublul Huda":

1. In the first place, Al-Shami describes this verse at this place in the chapter of the Prophet's name and its explanation. The purpose of point out here in his Seerah 
book is to inform us of the meaning of the Holy Prophet's name (Straight Path) "Al Serat al Mustaqim" PBUH.

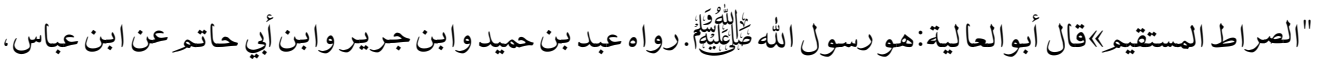

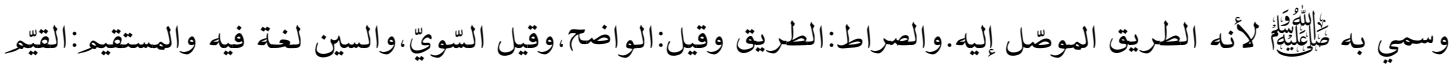

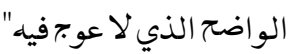

Abul-ul-Aaliyah says that the word "Al Serat al-Mushtaqim" refers to the Prophet Karim PBUH. This view has been narrated by Abdul bin Hameed, Ibn e Jarir and Ibn e Abi Hatim, and Abdullah bin Abbas state, The Prophet (peace be upon him) has been called "straight path")(صراط مستقيم) because it is the path accessor to the Holy Prophet PBUH. Imam Hakim narrated it and said it was right. And Al-Shami RA has mentioned here the different sayings in the interpretation of Al - Seraat: 1. path, 2.Open way, 3.The straight path and he was read the" "سراط" 'nرstead of " صر اط" And al-Mushtaqim: A path which is straight and clear, with no crookedness. ${ }^{19}$

2. In the $2^{\text {nd }}$ place, Al-Shami describes this verse at another place, in the chapter of the Prophet's name and its explanation. The purpose of describing here is to inform the meaning of the Holy Prophet's name "al Mustaqim" PBUH.

$$
\begin{aligned}
& \text { "المستقيم": اسم فاعل من الاستقامة وستأتي وأصله مستقومرنقلت حركة الواو إلى ما قبلها ثمرقلبت ياء، وهو الذي لا } \\
& \text { عو ب فيه ينقصه، أو السالك الطريق الهستقيم وهي طريق الحق فلايحول عنهاوقد مرّ عن الحسن وأبي العالية أبــ الصراط الهستقيم }
\end{aligned}
$$

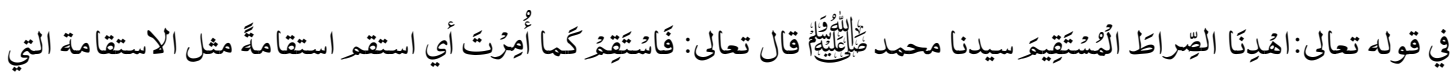

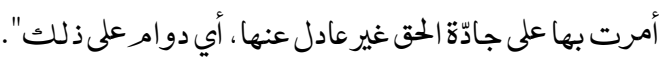

The Al- Mustaqeem is the root of the noun istaqama, and this was actually Mastaqoom direct transmitting the movement of the wow and then replacing the wow with yaa, and this means a way in which there is no oblique or rotation. This meant to the straight path, which is the path of truth and it cannot be left, and this discussion has already been done. By Hasan Basri and Abul Aaliyah, the meaning of ( اُحِنَّا الِِّراطَ

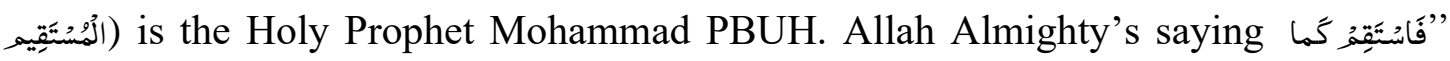
“أُمِرْنَ: Make the determination that you are commanded to stand in the way of truth, never leave it and remain forever. ${ }^{20}$

Respected teacher Abu al-Qasim al-Qashairi (75 h) says:

$$
\text { النف، ثم الاستقامة وهي تقرّب الأسرار" الاستة درجة بهال الأمور وتما مها. وبلوغها حصول الخيرات ونظامها، وأول مدارجها: التقويم وهو تأديب }
$$

Persistence is the degree to which matters reach the perfectionist end. At this stage, the pursuit of goodness is achieved, and the first level is the self-training, followed by the status of perseverance, and it is almost achieved closeness of mystery. ${ }^{21}$ Abu Abdullah Zurkani RA (1122 h) writes that: 


$$
\text { "الاستقامة الخروب من المعهودات ومفارقة الرسومو العادات والقيام بين يدى الحق على قدم الصّدق" : }
$$

And according to one view, persistence: Leaving famous worldly things and rituals, it is named strongly to be tossed to the right path. ${ }^{22}$

Imam Ibn Jarir al-Tabari ( $310 \mathrm{~h}$ ) says: In view, the best interpretation of this verse is as blow:

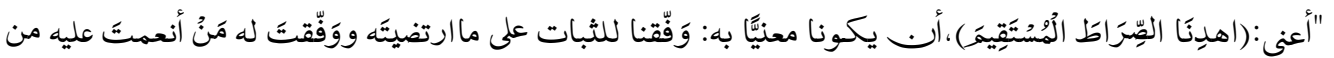

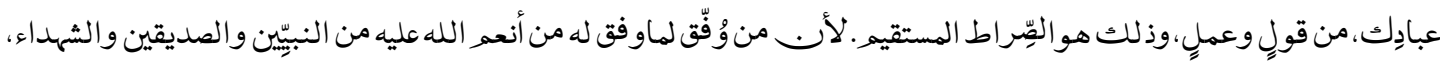

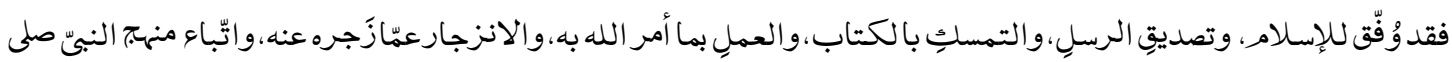

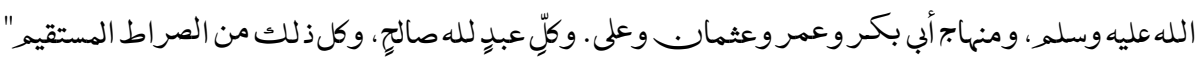

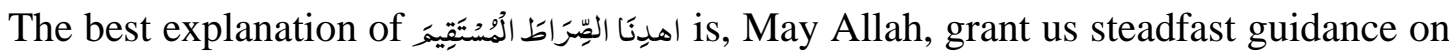
our path of choice and you have honored your award-winning servants with this reward, their viewpoint is in accordance with that, and this is the straightforward way. Therefore, the one who received the support of like the award-winning prophets and the martyrs, got the right path to practice religion. Confirmation of the Messengers, Relationship to the Holy Qur'an and Obedience to Allah, And following the mission of the Prophet PBUH, Abu Bakr RA, and Umar RA, and the way of every good man is called straight path. ${ }^{23}$

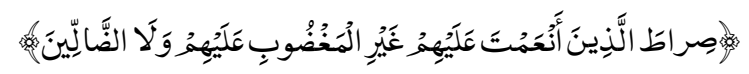

The path of those whom Allah has rewarded them, not the way of those who have been wroth and not of those who have gone astray. ${ }^{24}$

Imam Abdullah bin Yusuf Shami RA describes this verse at two deffrernt places and chapters in his book "Sublul Huda":

1. Allama Shami describes this part of the verse out in this chapter from the chapters on the rights of the Ummah of the Holy Prophet, mentioning your obedience to Holy Prophet PBUH and is said to be adopted His way of life. And the reason for being blessed by Allah Almighty a general is also called the follower of the Sunnah.

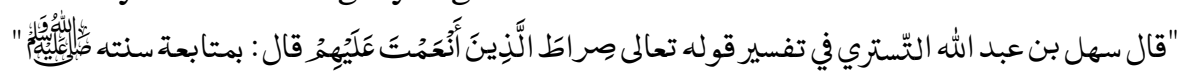

Sohail bin Abdullah Tastari RA says the explanation of this verse, He received this award because of His obeying and following the Sunnah of the Holy Prophet PBUH). ${ }^{25}$

Imam Ibn Jarir al-Tabari says about this verse (صِرَاطَ الَّذِينَ أَنْعَمَتَ عَلَيْهِهُ):

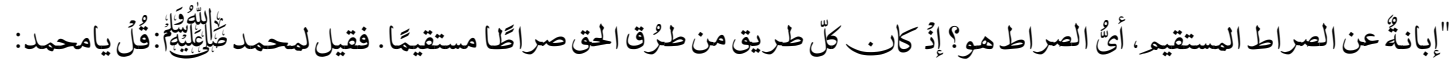

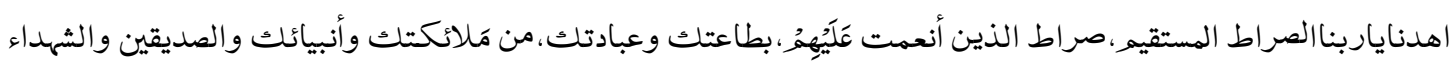

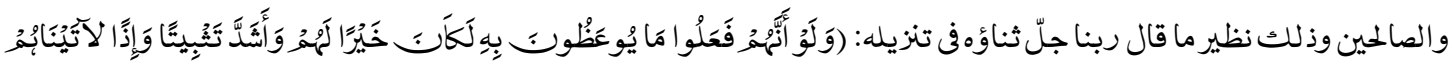

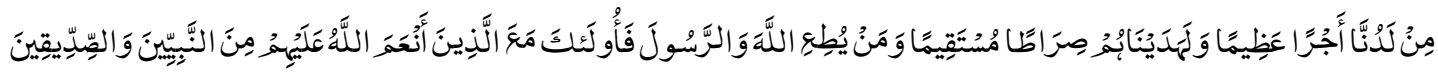


This is actually an explanation of a straightforward path, which is the way? While all the right paths are straightforward, The Prophet (peace and blessings of Allah be upon him) commanded, ask Allah to guide us to the way of the rewarded people, whom you have promised your obedience (and this privilege) bestows to angels, prophets, saints, martyrs, and the righteous. And similarly, the interpretation of Allaah exists in another place in the Quran "And if the people (of the people) act according to the admonition, it will be better for them, We would reward them and allow them to go straight, And whoever obeys Allah and His Messenger (blessings and peace be upon him) will be blessed with the rewarding people, the Prophets, the Siddiqins, the martyrs and the righteous. ${ }^{26}$

Allama Ibn Kathir $(774 \mathrm{~h})$ in the interpretation of this verse describes the sayings of Ibn Zayd and others.

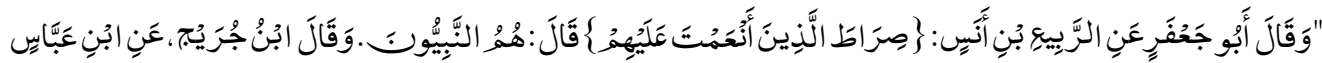

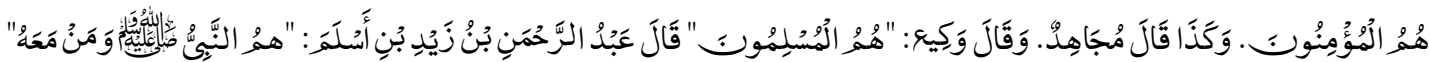

Abu Jafar narrates from Rabi ibn Anaseans the Prophets, while Ibn Jirajah quotes from Ibn 'Abbas that means is a believer, and so Mujahid says that the Wak'i said its meant Muslims. ${ }^{27}$ Abdurrahman ibn Zaid ibn Aslam says: "The

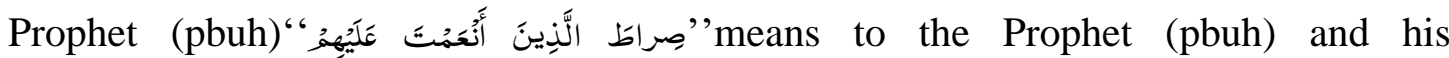
companions). ${ }^{28}$

2. Allama -Shami RA brings this verse in the chapter on the important aspects of the Seerah of Prophet PBUH from the chapters of Prayer Farz in which there is a statement praying with the Surah Al-Fatiha and saying Amin aloud. There are alpha words in different hadiths like lengthen and aloud his voices)(رفع بهاصوتهلمدمد بهاصوته) etc.

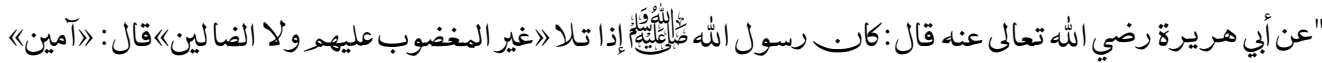

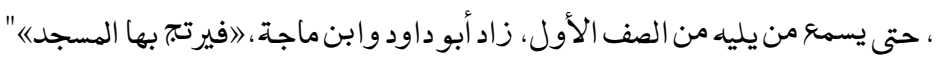

It is narrated from Abu Hurairah, The Messenger of Allah (PBUH) Said when غير Amen, Even the first row listened. Abu Dawood and Ibn Majah added that the mosque was echoing. ${ }^{29}$

Accurate straight, straightforward and clear way, and there have been called straightaway to the Prophet Muhammad PBUH, Abu Bakar, and Umar RA. Because they can not find this way without keeping their model of life. In this case, the accurate way cannot be left. In the same way that the Prophet PBUH, Abu Bakr Umar RA cannot be left out. Then Allah Almighty's winners are prophets, Siddiqins, martyrs, and the righteous, their behavior and the character are precisely according to straightway. And that is the source and quality of success and salvation. And its reputation is due to the obeying of the Holy Prophet PBUH, and so got the order from Shariah to obey and 
follow Him. Leaving the way of Holy Prophet PBUH is the reason and source of the distance and failure. Seekers of success and salvation will have to follow the path of success. On the other hand, Imam Shami has mentioned the meaning of the narration that the reward is given due to following the Prophet. And all the meanings are understood in it. Because whoever will follow the Prophet Mohammad PBUH, he will also be a true believer, he will be a Muslim and will also be on the methods of the prophet PBUH.

\section{Conclusion:}

Imam Shami RA is the one important scholar who wrote many books. His main book is on Seerah Al-Nabwia titled "Sublul Huda" which contains 14 volumes. In his book, he narrates Seerah Al-Nabwiah in different ways. He quotes the Holy verses of the Quran to Narrate the life of Mohammad PBUH. He brings one verse at different places to attain the different meanings narrating Seerah al-Nabi PBUH. So, we observed during the study of surat al-Fateha that he described the first verse Bismillah at two times, the $2^{\text {nd }}$ verse four times, the $4^{\text {th }}$ verse one time, $6^{\text {th }}$ verse two times and the last verse also described two times. He narrates different meaning describing the versed of the Holy Quran in different chapters and volumes. He did not discuss the verse $3^{\text {rd }}$ and $5^{\text {th }}$ in the whole book (Sublul Huda). Imam Shami RA also gives the arguments with Hadtids and quotations of other Imams and Scholars. We can understand his methodology that is used in his book Sublul Huda narrating Seerah Al-Nabwiah.

\section{Source and Base:}

${ }^{1}$ Al-Zarkali, Khair ud Din bin Mahmood bin Muhammad bin Ali (1396 h), Al-Ilaam, (Beirut: Dar ul Ilm, 2002), Vol. 07, P.155.

${ }^{2}$ Al-Basari, Abu al-Fida Ismail bin Umer (774 h), Qasas ul Ambia, (Qaira: Matbat Dar ul Talif, 1968), Vol. 01, P. 168.

${ }^{3}$ Hafiz,Prof Muaz, Imam Shami and Sublul Huda's introduction and his methodology, Fikr o Nazar, Islamic University Islamabad, Vol. 44, issue 02, P. 67

${ }^{4}$ Al-Quran, Surat al-Fateha 01:01

${ }^{5}$ Al-Dar Qutni, Al-Baghdadi, Abu al-Hassan, Ali bin Umer bin Ahmad, Sunna Al-Dar Qutni,

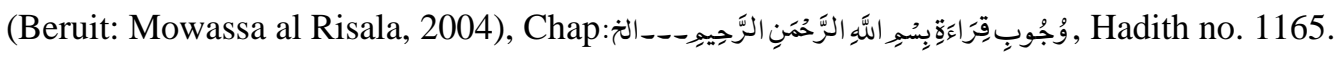

${ }^{6}$ Al-Shami, Muhammad bin Yosef, Sublul Huda, (Beruit: Dar ul Kutab al Ilmia ,1993), Vol. 08, P. 117.

${ }^{7}$ Al-Dar Qutni, Hadith no. 1175 / Al-Shami, Vol. 08, P. 498

${ }^{8}$ Surat Al-Fateha 01:02

${ }^{9}$ Al-Qushairi, Al-Naisaburi, Abu al-Hassan, Muslim bin Hajjaj (256 h), Al-Sahe al-Muslim,

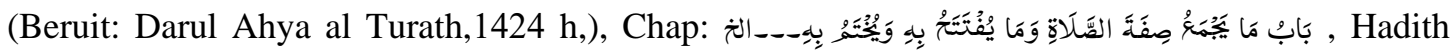
no498 / Al-Sajastani, Abu Dawud, Sulaiman bin Ash'th, Sunan Abu Dawud, translated by Yaser

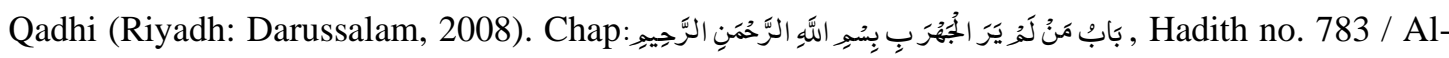
Qazwaini, abu Abdullah, Muhammad bin Yazeed, Ibn Maja, (273 h), (Beruit: Dar ul Ahya al

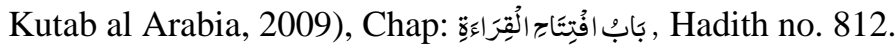




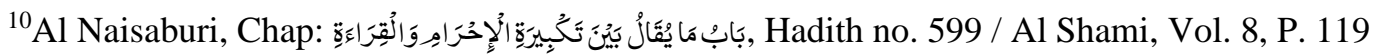

${ }^{11} \mathrm{Al}$ Tamimi, Abu Hatim, Muhammad bin Habban (354 h), Sahe Ibn e Habban (Beruit: Mowassa

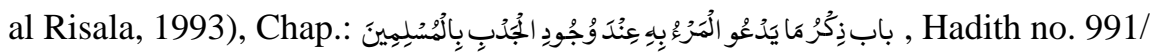

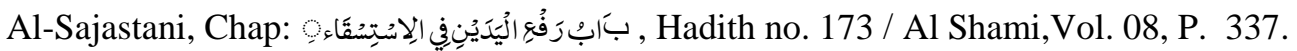

${ }^{12} \mathrm{Al}$ Bukhari,Al Juafi, Muhammad bin Ismail, al-Sahih al-Bukhari, (Beirut: Dar Touq al Najat,

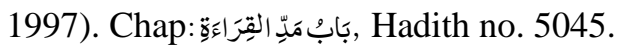

${ }^{13} \mathrm{Al}$ Shami, Vol. 08, P. 498.

${ }^{14} \mathrm{Al}$ - Shami, Vol. 10, P. 395.

${ }^{15}$ Al-Tibri, Muhammad bin Jarir (310 h.), Al-Jame al Bayan fi Taweel al Quran, (Beruit: Mowassa al Risala, 2000), V. 01, P. 143

${ }^{16}$ Surat al Fateha 01:04.

${ }^{17} \mathrm{Al}$ Tabrani, abul Qasim, Suleman bin Ahmad bin Ayoub bin Mutir (360 h), Nuajam al Owsateraral (Egypt: Dar ul Haramain, 1415 h), Vol. 08, P.123 / Al-Shami, V. 08, P.120

${ }^{18}$ Surat al Fateha 01:06.

${ }^{19} \mathrm{Al}$ Shami, Vol. 01, P. 482.

${ }^{20} \mathrm{Al}$ Shami, Vol. 01, P. 512.

${ }^{21}$ Ibid.

${ }^{22}$ Al Zarkani, Mohammad bin Abdul Baqi, Ab Abdullah, Sharah Lil Zurqani alal Mowahib alDunia, (Beirut: Dar ul kutab Ilmiah, 1417 h ), Vol.4 , P.216 / Al Shami, Vol.1, P.512

${ }^{23} \mathrm{Al}$ Tabri, Vol. 01, P. 171.

${ }^{24}$ Surat al Fateha 01:07.

${ }^{25} \mathrm{Al}$ Shami, Vol. 11, P. 428.

${ }^{26} \mathrm{Al}$ Tabri, Vol. 01, P. 177,178.

${ }^{27} \mathrm{Al}$ Damishqi, Ibn e Kaseer, Ismail bin Umer (774 h), Tafseer al Quran al Azeem, (Beirut: Dar ul Al kutab al Ilmia, 1419 h), Researcher: M. Hussain Shamash ud Din, Vol. 01, P. 140.

${ }^{28}$ Ibid

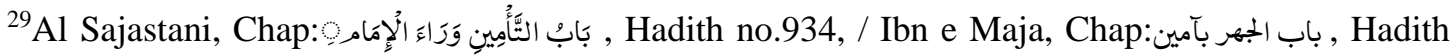
no853. / Al Shami, Vol. 08, P. 120

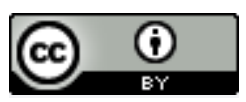

This work is licensed under a Creative Commons Attribution 4.0 International License. 